\title{
THE RESILIENCE OF WOMEN TOURISM WORKERS DURING THE Covid-19 PANDEMIC IN BALI
}

\author{
Ni Made Ary Widiastini ${ }^{1}$, Siti Annisa Silvia Rosa ${ }^{2}$, Roni Ekha Putera ${ }^{3}$, \\ Gabriella Susilowati ${ }^{4}$ and Totok Hari Wibowo ${ }^{5}$ \\ ${ }^{1}$ Ganesha University of Education, Bali, Indonesia \\ ${ }^{2}$ Indonesian Institute of Sciences, Bandung, Indonesia \\ ${ }^{3}$ Andalas University, Padang, Indonesia \\ ${ }^{4}$ Ministry of Agriculture, Indonesia \\ ${ }^{5}$ Association of Indonesian Policy Analysts \\ E-mail: ary.widiastini@gmail.com; sitiannisasr@gmail.com; roniekhaputera@gmail.com; \\ yez.kinanti@yahoo.com; thw311210@gmail.com
}

\begin{abstract}
This study aims to determine the form of resilience of women tourism workers affected by the Covid-19 pandemic. This study uses a qualitative method with a case study approach. Data sources are primary data from interviews with various parties, including hotel owners, hotel associations and hotel employees, while secondary data sources are documentation data. Data analysis was performed using an interactive model. The spread of the corona virus globally has affected various lines of community life, including in Bali. Hotels are the tourist facilities in Bali that are most affected. The decline in tourist visits, causing hotel occupancy rates to experience a drastic drop which resulted in layoffs. The finding of this research is that job termination for female employees occurs in almost every hotel in Bali. However, the termination of employment was responded creatively. In an effort to maintain a life for themselves and their families, women who are affected by hotel employees, especially those who have worked in the food and beverage division, react by adjusting to the conditions that occur. They make various types of food that are sold online using WhatsApp, I.G. and F.B. social media. The attitude of women who are former hotel workers in the food and beverage division in Bali towards termination of employment shows that creativity is driven by the spirit of survival as a modality that needs to be supported and worthy of being a good practice as well as a model on develop women's capacities during pandemic Covid-19 and new normal.
\end{abstract}

Keywords: Resilience; Women, Workers; Tourism; Pandemic; Bali

\section{RESILIENSI PEREMPUAN PEKERJA PARIWISATA MASA PANDEMI COVID-19 DI BALI}

\begin{abstract}
ABSTRAK. Penelitian ini bertujuan untuk mengetahui bentuk resiliensi wanita pekerja pariwisata yang terkena pandemi Covid-19. Penelitian ini menggunakan metode kualitatif dengan pendekatan studi kasus. Sumber data merupakan data primer dari hasil wawancara dengan berbagai pihak antara lain pemilik hotel, asosiasi hotel dan pegawai hotel, sedangkan sumber data sekunder adalah data dokumentasi. Analisis data dilakukan dengan menggunakan model interaktif. Penyebaran virus corona secara global telah mempengaruhi berbagai lini kehidupan masyarakat, termasuk di Bali. Hotel merupakan fasilitas wisata di Bali yang paling terpengaruh. Turunnya kunjungan wisatawan, menyebabkan tingkat hunian hotel mengalami penurunan drastis yang mengakibatkan pemutusan hubungan kerja. Temuan dari penelitian ini adalah bahwa pemutusan hubungan kerja bagi karyawan wanita terjadi hampir di setiap hotel di Bali. Namun pemutusan hubungan kerja ditanggapi secara kreatif. Dalam upaya mempertahankan kehidupan untuk diri sendiri dan keluarganya, wanita yang terkena dampak dari karyawan hotel terutama yang pernah bekerja di divisi makanan dan minuman bereaksi dengan menyesuaikan dengan kondisi yang terjadi. Mereka membuat berbagai jenis makanan yang dijual secara online menggunakan WhatsApp, I.G. dan F.B. media sosial. Sikap perempuan yang merupakan mantan pekerja hotel pada divisi makanan dan minuman di Bali terhadap pemutusan hubungan kerja menunjukkan bahwa kreativitas didorong oleh semangat bertahan hidup sebagai modalitas yang perlu didukung dan layak dijadikan praktik yang baik sekaligus sebagai model pengembangan kapasitas perempuan selama pandemi Covid-19 dan normal baru.
\end{abstract}

Kata kunci: Resiliensi; Perempuan; Mantan Pekeja; Pariwisata; Pandemi, Bali

\section{INTRODUCTION}

The rapid development of virus Covid- 19 causes a significant impact, especially on educational psychology, namely anxiety or excessive fear that results in panic buying. It is cause the health goods are difficult to obtain, in another hand the society also experience feelings of pressure, stress and anxiety.
Sufferers also feel panic in fear of being excluded from the environment when their privacy or identity is leaked to the public (Nurkholis, 2020). The massive and global spread of the Corona virus (Covid- 19) has resulted in weakening economic activity in various sectors and regions. In its movement, the coronavirus has put heavy pressure on the country's economy. Burhanuddin explained that the coronavirus could 
also negatively impact culture and public health (Burhanuddin et al., 2020). This occurs in Bali's condition, where most of the population depends on their source of income from the tourism sector.

The development of tourism in Bali in particular will create many jobs that can be utilized by women. There will also be more women who enter the work area of men, with gender issues still attractive (Suardana, 2006). However, this phenomenon continues to have an impact on efforts to increase the role of women in various sectors, and tourism is also hoped to be a way to increase the income of local communities (Suardana, 2006). During its development, culture and tourism have become a habitus (Suardana, 2006), in Balinese society that develops generatively. Furthermore, Bali's legitimization is one of the best tourist destinations at the national and international levels, supported by the availability of substantial capital, perfecting the Balinese people's movements in carrying out their social practices, namely making tourism as the primary economic source for them.

The lives of people in Bali, who mostly depend on their income on the tourism industry, have suddenly changed due to the spread of the Covid virus at the end of 2019. Slowly the level of tourist arrivals began to decline at the end of 2019, and in March it decreased sharply. Figure 1 shows that the decline in tourist arrivals in March 2020 occurred drastically, even being the lowest number of visits in the last four years.

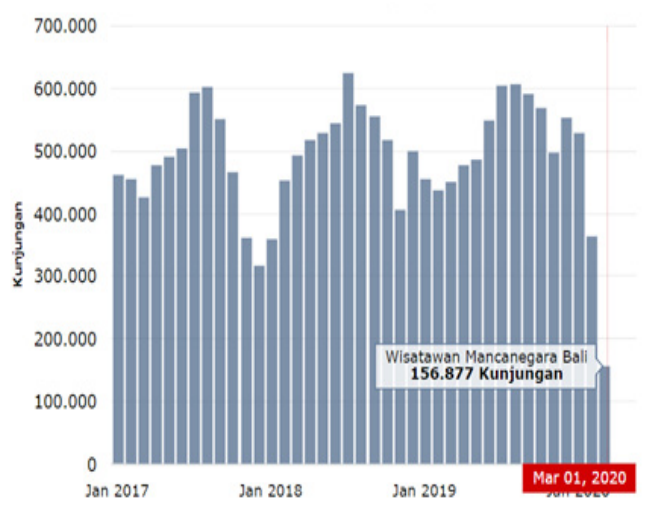

Source: Dwi Hadya Jayani, https://databoks.katadata.co.id/ datapublish/2020/07/13/wisman-ke-bali-hanya-36-orang-turunhampir-100-pada-mei-2020

Figure 1. Data on the Decrease in International Tourists

According to the data in figure 1 , foreign tourist arrival to Bali have drastically decreased during the Covid-19 pandemic. Especially in March 2020 , tourist visits fell to only 156,877 visitor. The decline in visitor during the Covid-19 pandemic has an impact on the dependence of Balinese people on tourism. In fact, their economic conditions during the Covid-19 pandemic worsened due to the sharp decline in visitor to Bali.
Kadafi on May 12, 2020, in his interview to the Head of the Bali Provincial Manpower Office, wrote that 65,594 formal workers were sent home and 2,189 people who were laid off. This number continues to increase in line with the delay or cancellation of visitor to Bali, which causes hotel occupancy to be unable to retain employees. In addition, hotels are also having difficulty knowing the virus spread sustainability, considering the massive spread of the virus. Likewise, social restrictions that still occur in several regions (Republic Indonesia Minister of Health Number 9 of 2020) and the state (Budiyanti, 2020), as well as the low purchasing power of both local and national communities, have resulted in tourism products not being able to be optimally absorbed by the market. based on interview to Agys Kusuma on July 17, 2020, the absence of significant income in the tourism business, especially hotels, provides the bitterest choice in the tourism business, namely termination of employment. Although the government routinely requests that employee layoffs be discontinued, the tourism business's poor financial condition makes the process of permanent employee dismissal unavoidable. Based on interviews conducted with three-star hotels in Bali, it was stated that in July the occupancy rate was still below $10 \%$, so the hotel management to make the decision to carry out an advanced stage of layoffs with hundreds of workers.

Women, as part of tourism workers, also receive the impact. In this study, there are unique things that are observed with the massive layoffs of employees in Bali, especially among women. In tourism, Balinese women who so far have the impression that they only exist as employees of the lower middle class, some of them works as entrepreneurs (Putra, 2018). However, the pandemic conditions had an impact on Balinese female workers. In practice, women tourism workers are quite alert in dealing with these conditions, especially those who work in the formal sector, such as hotels. Understanding himself has the ability to sell, directing them to do a variety of creativity, namely producing products that can be sold either directly or online.

Balinese women who are affected by Covid-19 have the ability to survive/resilience to get out of the problems they face. Even though the culinary business, they can get additional income to resume their lives during the Covid-19 pandemic. Culinary is an invasion for workers tourism's woman in Bali who are affected by the Corona virus. In particular, many of them have worked in hotels making various types of food that are sold to the general public. This condition is in line with (Đarma-Putra, 2018) findings, which emphasizes that Balinese women have exceptional abilities in the culinary field, which 
is evidenced by the existence of culinary businesses that are built and managed by Balinese women who are known not only locally, but also internationally.

Resilience has been widely used as an important aspect in the management of natural resources and the environment because it is a vital attribute that characterizes the capacity of a system to cope with vulnerable conditions (Shaleh, Abdoellah, \& Dhahiyat, 2014). Resilience generally leads to positive adaptation patterns during or after facing difficulties or risks. Resilience is an idea that refers to the capacity of a dynamic system to survive or recover from disturbances (Nofianti, 2016). Likewise, (Nurhayati \& Halal, R, 2020) states that resilience is a universal capacity that allows a person, group or community to prevent, minimize or overcome the damaging effects of adversity. Resilience is the human capacity to face and overcome difficulties and to be strengthened or transformed by difficulties in life.

The high wave of layoffs, loss of community livelihoods, followed by other impact such as the emergence of potential gender-based violence (such as; sexual violence, domestic violence, online gender-based violence and other forms of violence) experienced by women after the issuance of the determination of Covid- 19 as a National disaster in the Presidential Decree (Keppres) 12/2020 concerning the Determination of the Non-Natural Disaster for the Spread of Corona Virus Disease 2019 (COVID- 19) as a national disaster (PPPA, UNFPA, P2TP2A DKI Jakarta, Layanan, \& Pulih, 2020).

However, it is often found that human resilience in facing various life difficulties is less than optimal. Humans prefer to give in to circumstances or even experience various disturbances in social, mental or physical abilities. They are unable to maintain balance in the face of strong pressure (Utami, 2018). However, in contrast to Balinese women who work in the tourism sector affected by Covid-19, they persist and can even gain the ability to earn additional income in the form of businesses in the culinary sector.

\section{METHOD}

This study uses an ethnographic approach as a variant of the qualitative approach. The ethnographic approach is an empirical and theoretical approach that aims to obtain in-depth descriptions and analyzes of culture based on intensive field research (Morgan-Trimmer \& Wood, 2016). In this study, the ethnographic approach was carried out, including (1) entering the lives of women workers in the tourism sector; (2) looking at the work process of the habitus, domain, and capital undertaken by women workers in the tourism sector. In the early stages, before in- depth interviews were conducted with individuals selected using the Tremblay method (Marshall, 1996), questionnaires were distributed to women workers in the tourism sector via google form. The initial data obtained can be seen as follows.

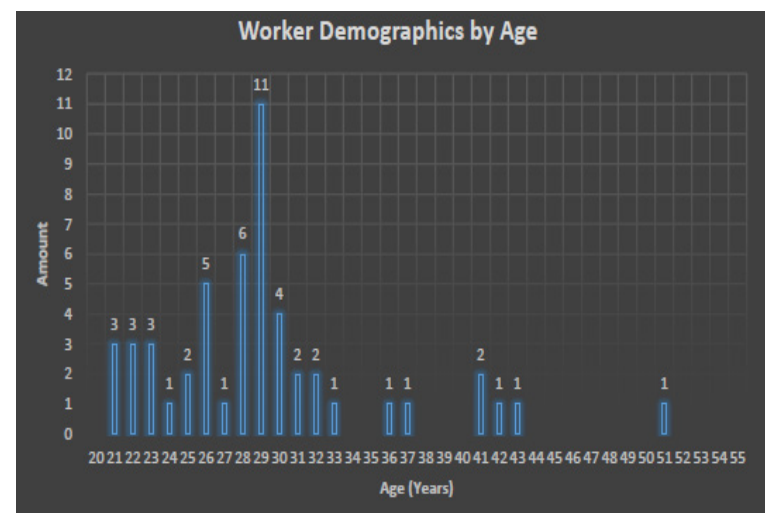

Figure 2. Demographics of Working Women in the Bali Tourism Sector Fill in Data Google Form

Based on the data above, mostly are works in hotels. Than, some of them also work for travel agents, restaurants, tourist attractions, and others. Subsequent interviews were conducted to corroborate the data generated by means of a questionnaire (google form). As with (Marshall, 1996), the selection of informants to be interviewed has characteristics including having a formal role that enables them to explain the information sought by researchers, has knowledge in accordance with the required data, can communicate their knowledge in a way that can be understood by the interviewer, and key informants must be objective and undisturbed. In the discussion, the findings were analyzed with a textual approach using the concept of differences as proposed by Derrida (Barker, 2014) and in the discussion of any matter, the theories used eclectic.

\section{RESULTS AND DISCUSSION}

Bali's tourism is cultural tourism, namely tourism based on Balinese culture, which is based on Hinduism (Wirartha, 2000) so that Bali tourism cannot be separated from Balinese customs and culture. This cultural tourism model can develop well if it can include all Balinese society levels as cultural supporters. In this community empowerment, it must not be forgotten that the empowerment of women. Empowerment of women in the tourism sector is quite interesting because the tourism sector is in the public sector, which is conventionally the work area of men. In contrast, women work in the domestic industry (Wirartha, 2000). In line with Bali tourism development, there will be many job opportunities that women can use. More and more women will enter men's work area with the consequences of gender issues facing them. This phenomenon 
makes it very interesting to study gender, especially regarding female workers in Bali's tourism sector (Wirartha, 2000).

\section{Profiles of Working Women in the Bali Tourism Industry}

The need for women as workers in the tourism industry, especially in Bali is relatively high. Even (Widiastini, Ardika, \& Mudana, 2018)Kintamani, Bangli Regency, Bali to make their family survive. However, the souvenir vendors' existence is not only considered by tourism businesses as unacceptable, but it is also regarded as a major factor that hampers the development of tourism in Kintamani. In fact, the Bali Local Regulation No. 2 of 2012 on Cultural Tourism explicitly emphasizes that the development of Bali's tourism is aimed to encourage an equal distribution of business opportunities and to obtain maximum benefits for the welfare of the community. Therefore, this study was aimed to determine the reasons why the informal sector (souvenir vending explained that women's interest in continuing their studies in the tourism sector was classified as high because the absorption of female graduates, especially in hotels, was also increased. The increased absorption of female graduates to work in tourism industry, is the reason women graduates of high/ vocational schools in Bali choose to continue their studies in tourism. Furthermore, in further research conducted by (Widiastini, Prayudi, \& Andiani, 2019), it was found that women graduates in the field of hospitality have job opportunities in vital positions that function to earn hotel income and manage the income received, including front liners and financial managers such as front office department, food and beverage service, sales and accounting.

Bali, as a tourist destination, has various types of tourist facilities with various classes that provide employment opportunities for the community, including women. Based on a survey conducted of female workers who are currently experiencing the impact of the pandemic, 59\% of them are hotel

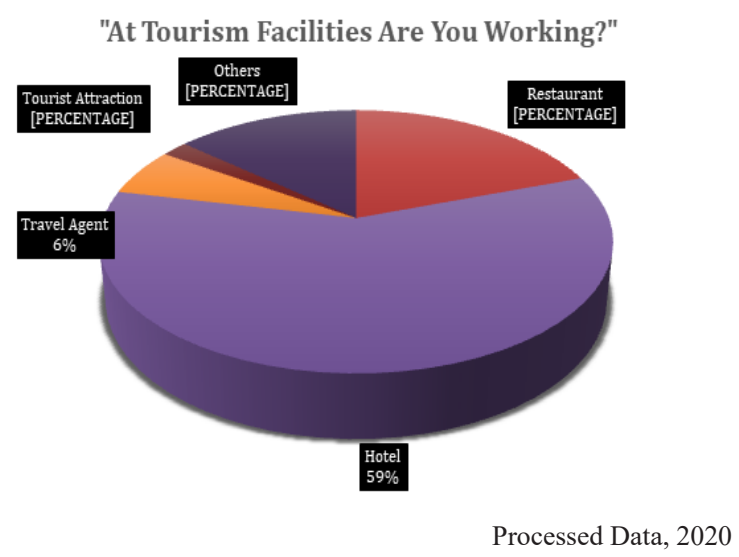

Figure 3. Workplace of Women in Tourism Facilities in Bali

workers, as can be seen in the following chart.

A hotel is a place to provide accommodation on a daily basis in the form of rooms in a building that can be equipped with food and drink services, entertainment activities and/or other facilities. A large number of star and non-star hotels in Bali has an impact on the presence of job opportunities at these tourist facilities, as can be seen in the following table 1 .

Bali, as one of the favourite destinations in Indonesia and the world, not only provides opportunities for entrepreneurs to build formal tourism facilities. In practice, tourists' presence has implications for the presence of small-scale inns, such as homestays, guest houses, and standard smal hotels (non star hotel), which in their construction require relatively less capital than star-rated hotels. Understanding the opportunities that arise resulting from tourism, the structure of non-star hotels also occurs very much, as shown in the following table.

Table 1. Number of Star Hotels in Bali

\begin{tabular}{|c|c|c|c|c|c|c|}
\hline \multirow{2}{*}{$\begin{array}{c}\text { Kabupaten/Kota } \\
\text { Regency/ } \\
\text { Municipality }\end{array}$} & \multicolumn{5}{|c|}{ Kelas Hotel/ Hotel Class } & \multirow{2}{*}{$\begin{array}{c}\text { Jumlah } \\
\text { Total }\end{array}$} \\
\hline & $\begin{array}{c}\text { Bintang } 5 \\
5 \text { star }\end{array}$ & $\begin{array}{c}\text { Bintang } 4 \\
4 \text { star }\end{array}$ & $\begin{array}{c}\text { Bintang } 3 \\
3 \text { star }\end{array}$ & $\begin{array}{c}\text { Bintang } 2 \\
2 \text { star }\end{array}$ & $\begin{array}{c}\text { Bintang } 1 \\
1 \text { star }\end{array}$ & \\
\hline (1) & (2) & (3) & (4) & (5) & (6) & (7) \\
\hline Jembrana & 0 & 1 & 3 & 1 & 0 & 5 \\
\hline Tabanan & 2 & 1 & 2 & 0 & 0 & 5 \\
\hline Badung & 62 & 118 & 158 & 48 & 8 & 394 \\
\hline Gianyar & 6 & 10 & 4 & 1 & 2 & 23 \\
\hline Klungkung & 0 & 0 & 0 & 0 & 2 & 2 \\
\hline Bangli & 0 & 0 & 0 & 0 & 0 & 0 \\
\hline Karangasem & 0 & 4 & 3 & 1 & 0 & 8 \\
\hline Buleleng & 2 & 4 & 11 & 3 & 0 & 20 \\
\hline Denpasar & 6 & 6 & 15 & 18 & 5 & 50 \\
\hline Bali & 78 & 144 & 196 & 72 & 17 & 507 \\
\hline
\end{tabular}


Table 2. Number of Star Hotels in Bali

\begin{tabular}{|c|c|c|c|c|c|}
\hline \multirow{2}{*}{$\begin{array}{c}\text { Kabupaten/Kota } \\
\text { Regency/Municipality }\end{array}$} & \multicolumn{4}{|c|}{$\begin{array}{l}\text { Kelompok Kamar } \\
\text { Room Available }\end{array}$} & \multirow{2}{*}{$\begin{array}{c}\text { Jumlah } \\
\text { Total }\end{array}$} \\
\hline & $<10$ & $10-24$ & $25-40$ & $>41$ & \\
\hline (1) & (2) & (3) & (4) & (5) & (6) \\
\hline Jembrana & 49 & 26 & 4 & 1 & 80 \\
\hline Tabanan & 109 & 44 & 15 & 2 & 170 \\
\hline Badung & 760 & 470 & 144 & 118 & 1492 \\
\hline Gianyar & 679 & 233 & 74 & 28 & 1014 \\
\hline Klungkung & 110 & 74 & 6 & 4 & 194 \\
\hline Bangli & 24 & 13 & 2 & 0 & 39 \\
\hline Karangasem & 205 & 89 & 16 & 3 & 313 \\
\hline Buleleng & 188 & 93 & 24 & 16 & 321 \\
\hline Denpasar & 68 & 127 & 57 & 37 & 289 \\
\hline Bali & 2192 & 1169 & 342 & 209 & 3912 \\
\hline
\end{tabular}

In practice, labour, including in tourism facilities, is an important factor in carrying out business operations, which will have an impact on the demands on business management to be able to optimize workforce so that companies can produce optimal performance (Maryono, 2009). Hotels, restaurants, travel and other business facilities as a business unit that sells service products, in practice, require their workers to be able to work well. It is expected that every workforce in the tourism business will be able to provide optimal satisfaction to consumers so that in the end, they can increase income in the industry. There are several factors that become the basis for consideration of business owners in accepting employees, namely work experience of job applicant. Based on a survey of women affected by the Covid-19 pandemic, the length of work of women in the tourism sector can be seen in the following chart.

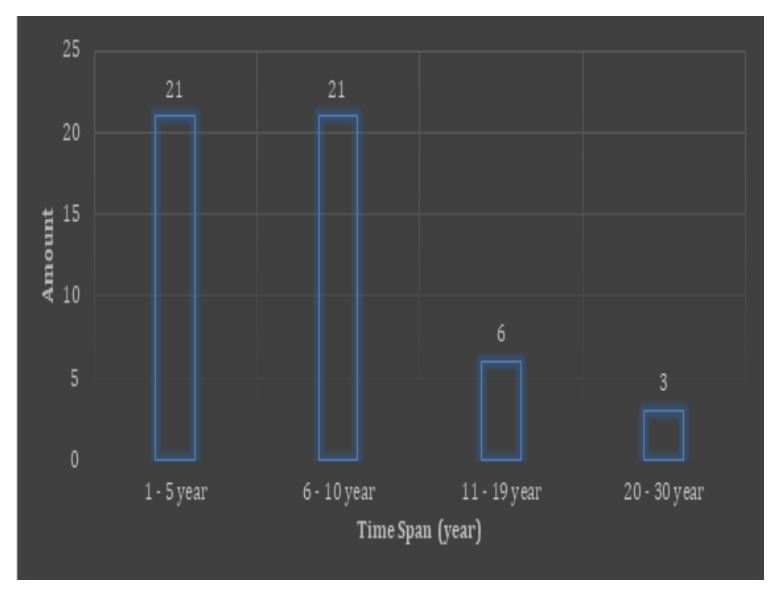

Source: Processed survey data using google form

Figure 4. How long Ilas it been working in the tourism sector

Based on the data obtained, women tourism workers, as seen in chart four above, are women who work in tourism in various fields of work, between 1 and 10 year. (Widiastini et.al, 2019) explained that the availability of a considerable number of female candidates who have competence in the tourism sector has an impact on the extensive job opportunities for female graduates. In addition, in her research (Widiastini et al., 2018)Kintamani, Bangli Regency, Bali to make their family survive. However, the souvenir vendors' existence is not only considered by tourism businesses as unacceptable, but it is also regarded as a major factor that hampers the development of tourism in Kintamani. In fact, the Bali Local Regulation No. 2 of 2012 on Cultural Tourism explicitly emphasizes that the development of Bali's tourism is aimed to encourage an equal distribution of business opportunities and to obtain maximum benefits for the welfare of the community. Therefore, this study was aimed to determine the reasons why the informal sector (souvenir vending, explain the high interest in women's studies in the tourism sector, giving women access to job opportunities in the tourism sector. Supported by the increasing availability of tourist facilities in Bali, namely in 2012 as many as 218-star hotels, to 551 in 2018 (Bali Province in Figures, 2020), of course employing female graduates in Bali. Likewise with the number of non-star hotels that increased by 2216 from 2012 to 2019.

In practice, women as workers in the tourism sector do not differentiate between work positions and salaries from men (Widiastini et al., 2019), but based on experience, competence and workability. Based on a survey given to women workers in the tourism sector who were affected by Covid, it is known that most women receive a salary of between IDR 2 - 5 million per month, which is around 42\% of the total respondents. Some even earned income above ten million rupiahs, namely $16.7 \%$ of the respondents. In this case, respondents who filled out the questionnaire worked as managers in hotels, who of course received relatively high salaries in accordance with their duties and responsibilities.

The income they get is income as long as they worked before the covid-19 pandemic. For them, this income has exceeded the basic needs of their family. The use of income is the use or expenditure for 
family needs. The use of income before the Covid-19 pandemic can meet the needs of their families, among others, to fulfil their daily basic needs, school needs, and family needs that are social in nature, such as recreation or simply expanding social relations in their community.

\section{The Impact of the Pandemic on Working Women in Bali Tourism Industry}

The condition of tourism in Bali in 2020 is the worst condition compared to Bali faced terrorist threats in 2002 and 2005, Sars disease in 2003 and the eruption of Agung Mount in 2017. As stated by (Dewi, Sunarta, \& Arida, 2020), which explains that tourism in practice, it involves human activities because it is a service industry, so the tourism industry is a disaster-prone industry. In the Covid- 19 pandemic, where there was a large-scale cut out of access, it had an impact on global human mobility (Djausal, Larasati, \& Muflihah, 2020). As a result, tourism activities (Burkart, \& Medlik, 1987), which is the movement of people from one place to another, which is the destination for tourism, are hampered. In fact, the spread of the virus, which was officially announced to have occurred in Indonesia on March 2, 2020, had an impact on social restrictions on various scales in several areas considered to have the potential for massive spread.

Bali as a tourist destination that has experienced a decline in the number of tourist visits since the end of 2019, with the presence of a positive community in Indonesia, the impact is the cancellation of tourist visits from various regions. Under these conditions, tourism facilities, especially hotels, travel agents, tourist attractions, tourist villages, and restaurants must accept the harsh reality that their customers cancel their orders. This in turn has an impact on decreasing the income of tourism workers, including women workers who have been depending on the tourism sector for their livelihoods.

What is the Management Policy on Employee Salaries while pandemic?

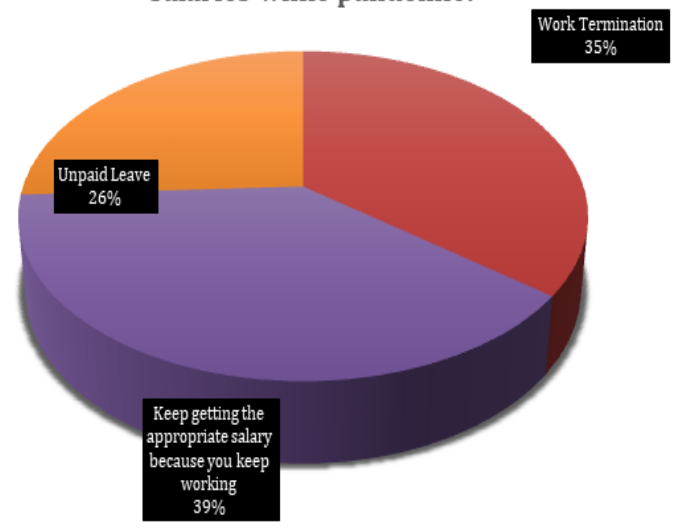

Processed Data, 2020

Figure 5. Management Policies for Women Tourism Workers in Bali
In the chart above, women who work in the tourism sector and have held high positions received policies from company management, namely $39 \%$ of women tourism workerstill receive salaries with the policy of each hotel, $26 \%$ are unpaid leave status, and $35 \%$ of the total respondents have termination working relationship. This condition causes a significant change in income for women tourism workers, which of course also affects their ability to be able to meet the needs of life and their families. Women (Utami, 2018; Widiastini et al., 2018) as individuals who at one time must have multiple roles, enabling them to take various ways to maintain their lives and the families they are responsible for.

\section{Resilience of Women Tourism Workers during the Covid-19 Pandemic in Bali}

Pandemic conditions have made almost all people in the world experience problems, both on health, economy, and society and culture. (Kavčič, Avsec, \& Zager Kocjan, 2020) in their study in Slovenia by conducting a survey of women, showed that women with younger age and less education have a higher chance of experiencing psychological problems. So that in his research, it is suggested that interventions be more focused on those who are young and less educated, where their understanding of their health is relatively low. In a different study, but also about women affected by the Covid-19 pandemic, (Nurhayati \& Halal, R, 2020) explained that the vulnerability of the pandemic condition is more experienced by women. The role of women is not only to protect their families from experiencing health problems but also requires them to be able to meet the necessities of life, especially those who are married.

Women as part of the family, which is the smallest social system in society, in practice, have an important role. Women, in this case as part of a family, which is a social system (Kanca, 2019) must be able to maintain the existence of their family, including during the pandemic. What can be done is to adapt to existing conditions. Based on the survey conducted, the ability to survive female workers who were affected in the conditions of the Covid-19 pandemic opened our eyes to the potential possessed by women. They have specific strategies to overcome the problems they face, as shown in the following chart 6 .

Women tourism workers affected by the pandemic in Bali have excellent adaptability. As stated by one of the respondents who worked at a hotel owned by a state-owned company, he immediately developed his sales ability to sell domestic products. Having experience in sales, they are able to see the market chance, and immediately try to develop the 
business of domestic product. Based on the survey, most of the women (54.4\%) chose to develop culinary products.

\section{(for those who have decreased income), if there is a decrease in income, what you do to survive and still be able to make ends meet}



- Looking for other jobs to increase income - Developing business skill

- Do nothing for some reason

Processed Data, 2020

Figure 6. Strategies for Coping with Decline in Income during a Pandemi

Involvement of women in the tourism sector in Bali can described as two group, namely the upper and middle and lower strata. The upper strata group, the involvement of women is quite high.. This can be seen from their activeness in the activities themselves, as well as their high level of involvement in tourism activities both at regional and national levels. Their chances of developing are also quite high because they have the same opportunity to take advantage of existing resources for their business development. The lower and middle groups, although they have been quite actively involved, their opportunities for development are hampered by their lack of professionalism, skills and managerial development. They think that their current position is good enough, compared to how they would be if they weren't working. In general, these two strata of women feel that their involvement in the tourism sector has provided social, cultural and economic benefits (Suardana, 2006).

Increasing resilience is an important task because it can provide experiences for humans in facing life's challenges and difficulties. Balinese women have the strength to survive and even get out of conditions that were considered very harsh during the Covid-19 pandemic. Various efforts were made during a pandemic, such as doing business in person or online and in the culinary business, providing additional income for them to survive. Previously they worked in the tourism sector earning quite a lot of income, but during the pandemic, they have to try to be able to fulfill their lives creatively. (Darma
Putra, 2018) who specifically researches and writes about the roles of four Balinese women who develop businesses, has successfully supported sustainable tourism programs. In this case, culinary is the main human need, wherever it is.

The Covid-19 pandemic has hit the community until in the lower class, and therefore in carrying out their family's economic resilience, they take advantage of business opportunities so that they manage to get out of the situation of fear of Covid-19 by running economic productivity. This economic activity is used as a support for the family economy during the Covid-19 pandemic. This form of the business group is also a means of community social resilience in empowering communities through small businesses. The empowerment of this group relies on local social capital that is built between communities (Rupita, 2020).

By increasing resilience, humans can develop life skills such as how to communicate, realistic abilities in making life plans and being able to take the right steps for their lives (Rojas F., 2015). They will develop ways to turn a stressful situation into an opportunity for personal development (Utami, 2018). The affected resilience of women workers in the tourism sector in Bali is to have a strategy to open a culinary business to increase their income.

\section{CONCLUSION}

The resilience of female workers who work in the tourism sector affected by Covid-19 is carried out by them in various positions in hotels. This study aims to determine the form of resilience of women tourism workers which is assessed by understanding the profile of women workers in the Bali tourism industry and the impact of the pandemic on women workers in the Bali tourism industry. The covid-19 pandemic has had a negative impact on hotel operations and revenues, which has implications for female workers in the tourism sector. Than, they to be unpaid leave worker and got work termination. Under these conditions, some of those who experience reduced working hours and layoffs try to exercise resilience by trying to develop a domestic product business, which in practice is still needed by the community. Based on a survey conducted by fifty-seven women and in-depth interviews with five respondents who were considered to have the criteria according to Tremblay's guidelines, it was found that culinary products were the choice for women tourism workers affected by Covid-19. In this case, traditional snacks, side dishes, and modern cakes are the products most in demand by the market. To reach the market, they use marketing by utilizing social media in selling their culinary products. 


\section{ACKNOWLEDGEMENT}

This study was supported by a research grant for policy advocacy for empowering the role of women affected by pandemic covid-19 funded by the ministry of research and technology / national research and innovation agency and education fund management institutions, ministry of finance, Indonesia.

\section{REFERENCES}

Barker, Chris. (2014). Kamus Kajian Budaya. Yogyakarta:Kanisius

Darma Putra, I. N. (2018). Masih Identik dengan Peran Domestik?: Implikasi Perkembangan Pariwisata pada Dinamika Relasi Gender di Bali.

Dewi, G.A.M., Sunarta, I.N. \& Arida, I.N.S. (2020). Gunung Agung Oleh Pelaku Pariwisata Ubud Pendahuluan. Jumpa, 7(Juli 2020), 107-127.

Djausal, G. P., Larasati, A., \& Muflihah, L. (2020). Strategi Pariwisata Ekologis Dalam Tantangan Masa Pandemik Covid-19. Jurnal Perspektif Bisnis, 3(1), 57-61. https://doi.org/10.23960/ jpb.v3i1.15

Kanca, I.N. Wi. I.N. (2019). Pembangunan Pariwisata Global di Bali. Media Bina Ilmiah, 22(4), 1673-1680.

Kavčič, T., Avsec, A., \& Zager Kocjan, G. (2020). Psychological Functioning of Slovene Adults during the COVID-19 Pandemic: Does Resilience Matter? Psychiatric Quarterly. 92, 207-216 https://doi.org/10.1007/s11126-02009789-4

Marshall, M. (1996). The Key Informant Technique. International Journal of Mathematical Models and Methods in Applied Sciences, 13(1), 92-97.

Maryono. (2009). Tenaga Kontrak: Manfaat Dan Permasalahannya. Jurnal Bisnis Dan Ekonomi (JBE), 16(1), 26-31.

Morgan-Trimmer, S. \& Wood, F. (2016). Ethnographic methods for process evaluations of complex health behaviour interventions. Trials, 17(1), 1-11. https://doi.org/10.1186/s13063-016$1340-2$

Nofianti, L. (2016). Perempuan Di Sektor Publik. Marwah: Jurnal Perempuan, Agama Dan Jender, 15(1), 51. https://doi.org/10.24014/ marwah.v15i1.2635

Nurhayati, T., \& Halal, R, S. A. (2020). Emansipasi Melawan Pandemi Global; Bukti Dari
Indonesia. Jurnal Adalah: Buletin Hukum Dan Keadilan, 4(1), 81-92.

Nurkholis. (2020). Dampak Pandemi Novel-Corona Virus Disiase ( Covid-19) Terhadap Psikologi Dan Pendidikan Serta Kebijakan Pemerintah. Pgsd, 6(1), 39-49. Retrieved from https://ejournal.umc.ac.id/index.php/JPS

PPPA, D.B.P. - K., UNFPA, P2TP2A DKI Jakarta, F., Layanan, P., \& Pulih, Y. (2020). Protokol Penanganan Kasus Kekerasan terhadap Perempuan di Masa Pandemi Covid-19. Deputi Perlindungan Hak Perempuan Kementerian Pemberdayaan Perempuan Dan Perlindungan Anak R.I. Retrieved from https://covid19.go.id/

Rojas F., L. F. (2015). Factors Affecting Academic Resilience in Middle School Students: A Case Study. GiST Education and Learning Research Journal, 11(11), 63-78. https://doi. org/10.26817/16925777.286

Rupita. (2020). Community Empowerment As a Form of Community Social Resilience Facing the Impact of Covid-19. Sosiohumaniora, 22(3), 348. https://doi.org/10.24198/ sosiohumaniora.v22i3.29727

Shaleh, M., Abdoellah, O. S. \& Dhahiyat, Y. (2014). Resiliensi Sosial Terkait Akses Sumber Daya Masyarakat Nelayan: Perspektif Political Ecology. Sosiohumaniora, 16(3), 290. https:// doi.org/10.24198/sosiohumaniora.v16i3.5769

Suardana, I. W. (2006). Pemberdayaan Perempuan Di Kawasan Kuta Sebagai Upaya Peningkatan Kualitas Pariwisata Bali. Piramida, 6(2), $1-16$.

Utami, N. P. (2018). Kebertahanan Perempuan Simalanggang. Turast: Jurnal Penelitian Dan Pengabdian, 6(1), 25-36.

Widiastini, N.M.A., Ardika, I.W. \& Mudana, I.G. (2018). A Defense of Local People Working as Souvenir Vendors and Its Relation with the Female Identity in Kintamani Tourism Area, Bali. Jurnal Humaniora, 30(2), 109. https:// doi.org/10.22146/jh.v30i2.32196

Widiastini, N.M.A., Prayudi, M.A. \& Andiani, N. D. (2019). Why do Women Choose to Continue Their Studies in Tourism? 69(Teams 2018), 117-126. https://doi.org/10.2991/ teams-18.2019.21

Wirartha, I. (2000). Ketidakadilan Jender Yang Dialami Pekerja Perempuan Di Daerah Pariwisata. SOCA: Socioeconomics of Agriculture and Agribusiness, $0(1), 1-11$. 